\title{
Biofertilizers and citrus cultivation
}

\begin{abstract}
Summary
Citrus trees (Citrus spp.) one of the main fruit crops worldwide, currently, due to excessive use of inorganic fertilizers, there is a serious threat to human health and the environment. The use of various types of biofertilizers like nitrogen fixers, phosphorus solubilizers, phosphorus mobilizers, and potassium solubilizers enhancing citrus growth, both directly by increasing resource acquisition (nitrogen, phosphorus, and essential minerals), producing Siderophore, stimulate Phytohormone production, or indirectly by increase plant tolerance of pathogens as a part of integrated pest management, and maintain soil fertility and protect the environment.
\end{abstract}

Keywords: biofertilizers, citrus tree, arbuscular mycorrhizae, siderophore production
Volume 5 Issue 4 - 2020

\author{
Waleed Fouad Abobatta \\ Citrus Research Department, Horticulture Research Institute, \\ Agriculture research center, Egypt
}

Correspondence: Waleed Fouad Abobatta, Citrus Research Department- Horticulture Research Institute- Agriculture research center- Giza, Egypt, Email wabobata@yahoo.com

Received: June 18, 2020 | Published: August 21,2020

\section{Background}

Citrus trees (Citrus spp.) considered one of the important fruit crops in different countries worldwide particularly in arid and semiarid regions, citrus cultivating in 140 countries approximately, ${ }^{1}$ the genus of Citrus is one of Rutaceae family, most commercially species belong to genus citrus such as Sweet orange, Mandarin, Lime, Lemon, Sweet lime, Grapefruit, etc. There are different abiotic and biotic factors that affect Citricultural like temperature, drought, soil salinity, agricultural practice, pests, and diseases. ${ }^{2}$

There are different challenges for citrus cultivation, whereas biotic stress represents a serious threat particularly under climate change conditions, the main biotic stresses including fungal, bacterial, viruses' diseases, and Nematodes, consequently, management practices changed in major ways as a response to biotic and abiotic stresses.

Biofertilizers considered an important alternative to control pests and pathogens and protect in citrus orchards, produce more healthy fruits and protect the environment as a part of biological control strategy, it could play an important role in providing healthy agricultural commodities supply, as safer substances could alternate partially the agrochemicals which caused serious environmental and health problems.

There are various biofertilizers have emerged as a promising alternative to chemical pesticides and have been successfully applied in different fruit crops to increasing nutrients availability and control pests and diseases. Biological fertilizers have a key role in citrus productivity and could be a promising solution to sustain soil health, and maintain the environment and ecosystem stability, produce safer fruits, and minimizing production costs. ${ }^{3,4}$

There are previously reviews explaining the impact of biofertilizers on different crop growth and productivity, while, we looking to provide a detailed review exploring the potential role of biofertilizers in citrus cultivation, the objective of this work was to discuss the role of biofertilizers in citrus cultivations as an alternative to agrochemicals under climate change conditions to sustain citriculture, protect the environment, and produce a safer commodity.

\section{Materials and methods}

The work was arranged by focusing on the importance of biofertilizers, exploring the various Benefits of Biofertilizers, direct and indirect Mechanism of Biofertilizers, explaining the correlation between biofertilizers and citrus cultivation, ending with the role of Arbuscular Mycorrhizae in citriculture.

\section{Biofertilizers}

Biofertilizers according to Vessey ${ }^{5}$ is a substance that contains living microorganisms which applied to the soil, plant, or seed surfaces colonize the rhizosphere or the interior of the plant and promote growth by increasing the supply or availability of nutrients the host plant. In other words, bio-fertilizer is an efficient type of organic fertilizer, which combined beneficial microorganisms and organic fertilizers in a new form.

Biofertilizers include various organisms mainly bacteria, fungi, and Algae that have a strong relationship with plant roots and inhabiting the root system or rhizosphere, like nitrogen fixers, phosphorus solubilizers, phosphorus mobilizers, and potassium solubilizers, controlling citrus canker. ${ }^{6}$ Biofertilizers increase nutrients availability for plants which considered an essential practice for citrus production and enhancing soil fertility. ${ }^{7}$ There are numerous advantages for biofertilizers application in agricultural biotechnology, also, there is an indirect role for biofertilizers in the availability of nutrient for the plant through produce enzymes like (nitrogenase, chitinases, and glucanases) due to increase the microbial metabolism in soil. ${ }^{8}$

Biofertilizers increasing the nutrients availability to the plants by the help of microorganisms, currently, there is more attention to use biofertilizers for improving plant growth, increase yield, nutritional status and reduced the accumulation of nitrate and nitrite in fruits and plant tissues, enhancing soil fertility, protect the environment, and 
reduce contamination of groundwater and waterway eutrophication by different chemical compounds. ${ }^{9}$

\section{Why biofertilizers?}

Biofertilizers could be a secure alternative strategy replacement the chemical fertilizers and pesticides to reduce environmental pollution, it's cost-effective, eco-friendly and it's easy to produce in farms directly. Also, there are various direct benefits of Biofertilizers like increase crop yield, fixing nitrogen, solubilizing phosphorus, improving plant growth, stimulate plant resistance against pests and diseases, enhancing soil vitality, improving soil properties. ${ }^{10}$

\section{Benefits of biofertilizers}

Previous scientific studies have indicated the beneficial role of biofertilizers in plant protection, stimulate growth and productivity when plants inoculated or fertilizing with various types of microorganisms like Rhizobacteria, Pseudomonas, and Mycorrhiza. ${ }^{11-14}$

Bio-fertilizers could play an important role in enhancing growth, nutritional status, and productivity of Washington Navel orange, ${ }^{15}$ also, limiting the accumulation of nitrate and nitrite in various fruits, ${ }^{16}$ benefits of biofertilizers includes among others:

a. Economic concerns, it's a very cheap source for different nutrients (Macro and micronutrients) compared to chemical fertilizers $^{3}$

b. Provided healthy and high-quality products, safe for human and animal use. ${ }^{17}$

c. Increase nutrient availability (includes macro elements) for plants. $^{18}$ d. Ecofriendly and protect the environment from pollution. ${ }^{19}$

e. Improve soil vitality, enhancing soil texture, $\mathrm{pH}$ and other properties of soil. ${ }^{20}$

There are microbes support their host plants, stimulates plant growth, increase plant resistance to pathogen infection, increases yield, and stimulate plant tolerance for some abiotic stress like soil salinity. ${ }^{21}$

\section{Citrus and biofertilizers}

The soils of citrus orchards in arid and semiarid regions are characterized by alkalinity and low contents of organic matter, therefore, the annual application of high rates of inorganic fertilizer is usually practiced by growers to maintain citrus productivity, besides, this annual application resulted in accumulation high level of soil Phosphorus, which leads to decrease in the efficiency of use Phosphorus, also, soil and water table are polluted with nitrite and nitrate, also, it's affecting farmers 'income. In this context, according to the World Health Organization recommendations, there is more demand for healthy and "high-quality fresh citrus" with minimizing residual materials to approved levels, ${ }^{22}$ also, biofertilizers assist to produce more safe fruits characterized by low nitrite and nitrate in fruits and protect humans health from various injures, also, as economic concerns, biofertilizers reduced use of inorganic fertilizers particularly Phosphorus fertilizers, ${ }^{23}$ there are various potential biofertilizers could be used like Azotobacter, Beijerinkia, Clostridium, Klebsiella, Anabaena, Nostoc, Rhizobium, Frankia, Anabaena azollae and Arbuscular mycorrhizal (Table 1), for that, there is more interest in stimulated biofertilizers in citrus orchards as a part of integrated management in sustainable agriculture. ${ }^{24}$

Table I Biofertilizers used in various citrus cultivation

\begin{tabular}{|c|c|c|c|c|}
\hline No & Bio-agent & Crop & Scientific Name & Reference \\
\hline I & $\begin{array}{l}\text { Bacillus circulance, B. poylmyxa, B. megatherium, } \\
\text { Candida spp,Trichoderma spp }\end{array}$ & Valencia orange tree & $\begin{array}{l}\text { Citrus sinensis } \\
\text { L. Osbeck }\end{array}$ & El-Aidy et al. ${ }^{17}$ \\
\hline 2 & Azotobacter spp., Arbuscular Mycorrhiza & Lemon Tree & Citrus limon Burm & Ghosh et al. ${ }^{22}$ \\
\hline 3 & Azotobacter spp. & Sweet Orange Trees & $\begin{array}{l}\text { Citrus sinensis } \\
\text { L. Osbeck }\end{array}$ & Jugnake et al." \\
\hline 4 & Arbuscular Mycorrhiza & Sour Orange seedlings & Citrus aurantium & Al-Karaki ${ }^{23}$ \\
\hline 5 & $\begin{array}{l}\text { Bacillus circulans, B.megaterium, Azotobacter } \\
\text { chroococcum }\end{array}$ & Balady Mandarin Trees & citrus reticulata & El-Shazly et al. ${ }^{27}$ \\
\hline 6 & Azospirillum spp., Bacillus megatherium & Navel Orange Tree & $\begin{array}{l}\text { Citrus sinensis } \\
\text { L. Osbeck }\end{array}$ & Zahgloul et al..$^{50}$ \\
\hline 7 & Azospirillum spp.,Arbuscular Mycorrhiza & Rough Lemon seedlings & Citrus jambhiri Lush.) & Singh et al. ${ }^{28}$ \\
\hline 8 & $\begin{array}{l}\text { Nitrobin ( } N \text {-fixing bacteria), } \\
\text { Phosphoren (P-dissolved bacteria) }\end{array}$ & Mandarin varieties Trees & Citrus spp. & El Khayat and Abdel Rehiem ${ }^{29}$ \\
\hline 9 & Azospirillum Lipoferum & Navel orange tree; & $\begin{array}{l}\text { Citrus sinensis } \\
\text { L. Osbeck }\end{array}$ & Abd El-Migeed et al. ${ }^{32}$ \\
\hline 10 & Azotobacter spp. & Kinnow Mandarin & Citrus reticulata & Bakshi et al., ${ }^{26}$ \\
\hline 11 & Arbuscular Mycorrhiza & Trifoliate Orange seedling & Poncirus trifoliata & Liu et al. ${ }^{54}$ \\
\hline
\end{tabular}


Table Continued...

\begin{tabular}{|c|c|c|c|c|}
\hline No & Bio-agent & Crop & Scientific Name & Reference \\
\hline 12 & $\begin{array}{l}\text { Azotobacter chrocoocum, Bacillus megatherium var } \\
\text { phosphaticum }\end{array}$ & Bitter Orange Seedlings & Citrus aurantium & Ismail et al. ${ }^{31}$ \\
\hline \multirow[t]{2}{*}{13} & $\begin{array}{l}\text { Azospirillum lipoferum, Bacillus megaterium, } \\
\text { Bacillus circulans }\end{array}$ & $\begin{array}{l}\text { Washington Navel orange } \\
\text { trees }\end{array}$ & Citrus sinensis & Zayan et al. ${ }^{33}$ \\
\hline & & & L. Osbeck & \\
\hline \multirow[t]{2}{*}{14} & Cyanobacteria,Azolla & Valencia orange Trees & Citrus sinensis & Mohamed et al. ${ }^{25}$ \\
\hline & & & L. Osbeck & \\
\hline 15 & Spirulina plantensis Algae & Balady lime tree & citrus aruntifollia & Masoud, and Abd Elaal ${ }^{34}$ \\
\hline 16 & Azotobacter spp. & Eureka Lemon Trees & Citrus limon (L.) Burm) & Ennab $^{35}$ \\
\hline 17 & Arbuscular Mycorrhizal & Kinnow Mandarin Tree & Citrus reticulata & Usha et al. ${ }^{36}$ \\
\hline \multirow[t]{2}{*}{18} & Azotobacter spp. & Valencia orange Tree & Citrus sinensis & Ali et al..$^{51}$ \\
\hline & & & L. Osbeck & \\
\hline 19 & Bacillus. velezensis, Pseudomonas aeruginosa & Pan-lime seedlings and trees & Citrus aurantifolia & Sudyoung et al. ${ }^{37}$ \\
\hline \multirow[t]{2}{*}{20} & Azospirillum brasilense, Pseudomonas fluorescence & Washington Navel orange & Citrus sinensis & Shamseldin et al. ${ }^{30}$ \\
\hline & & & L. Osbeck & \\
\hline
\end{tabular}

Indeed, previous studies in many areas of the world have been reported that there is a positive correlation between citrus growth and inoculation with biofertilizers which had great impacts through releasing, phosphorus, organic acids, and siderophore, etc.., (Table 1), (Ghosh et al. ${ }^{22}$ on Lemon (Citrus limon Burm.); Al-Karak ${ }^{23}$ on seedlings of Sour Orange (Citrus aurantium); Mohamed et al. ${ }^{25}$ on Valencia orange tree (Citrus sinensis L. Osbeck); Bakshi et al. ${ }^{26}$ on Kinnow Mandarin (Citrus reticulata); El-Shazly et al. ${ }^{27}$ on Washington Navel Trees (Citrus sinensis L. Osbeck); Singh et al. ${ }^{28}$ on Rough lemon seedlings (Citrus jambhiri Lush), El-Aidy et al., ${ }^{17}$ working on Valencia orangetrees (Citrus sinensis L. Osbeck); El Khayat and Abdel Rehiem ${ }^{29}$ working on mandarin varieties (Citrus spp.), Shamseldin, et al..$^{30}$ on Washington navel orange tree (Citrus sinensis L. Osbeck); Ismail, et al. ${ }^{31}$ on Bitter Orange Seedlings (Citrus aurantium); Ali et al. ${ }^{32}$ working on Valencia orange (Citrus sinensis L. Osbeck); Zayan, et al. ${ }^{33}$ on Eureka Lemon trees, Mohamed et al. ${ }^{25}$ working on Valencia Orange orange (Citrus sinensis L. Osbeck); Masoud, and Abd Elaal, ${ }^{34}$ working on Balady lime (citrus aruntifollia); Ennab HA ${ }^{35}$ on Eureka Lemon Trees (Citrus limon (L.) Burm); Usha et al. ${ }^{36}$ on Kinnow mandarin (Citrus reticulata), and Sudyoung et al. ${ }^{37}$ on Pan-lime (Citrus aurantifolia).

Therefore the inoculation with biofertilizers particularly mycorrhizal at various growth stages of citrus orchards particularly under stress conditions is the right strategy to stimulate tree growth and productivity, also, biofertilizers application enhancing the growth of citrus through increased the availability of different nutrients in the soil acquisition, improve their absorption and utilization, modifying soil $\mathrm{pH}$, secretion various organic materials in rhizosphere like organic acids, plant growth regulators which positively stimulated plant growth. ${ }^{38}$

\section{Mechanism of biofertilizers}

Biofertilizers stimulate plant growth by the alteration of the whole microbial community in the rhizosphere through the direct way by the production of various substances (like nutrients and plant hormones) or indirect mechanisms through stimulating plant defense by enriching systemic resistance to limiting the inhibitory effects of soil pathogens on plant growth. ${ }^{39-41}$

Indeed, there are various hypotheses try explaining the mechanisms of biofertilizers and their stimulation influence of plant growth which is not fully understood but includes among others:

A. Promoting production or affect concentrations of hormones in plants. $^{38}$

B. Fixation Nitrogen non-symbiotically. ${ }^{42}$

C. Solubilizing complex nutrients forms such as Dolomite, Feldspar, Phosphate, and other nutrients. ${ }^{43}$

\section{Direct mechanisms}

Biofertilizers play direct role in improving plant growth by increasing nutrients acquisition (i.e. nitrogen, phosphorus, siderophore production, potassium solubilizers, and other minerals), or enhancing Phytohormone Production. ${ }^{44,45}$

i. Nitrogen fixation: Biofertilizers play a key role in fixing the atmospheric N2, there are different types of microorganisms could fixing Nitrogen, it's classified to:

ii. Symbiotic $\mathbf{2} 2$ fixing bacteria: there are various bacteria that have the ability to fixing N2 symbiotically within leguminous crops particularly from family Rhizobiaceae which contain about numerous species, while, Frankia spp. associated with a non-leguminous woody plant. ${ }^{46}$

iii. Non-symbiotic N2 fixing organisms: there is a free-living organisms fixing nitrogen in associative form or endophytes one, like cyanobacteria, Azospirillum, Azotobacter, Gluconoacetobacter, diazotrophicus, and Azocarus, etc... ${ }^{47}$

\section{Siderophore production}

Citrus as a valuable crop is susceptible to iron chlorosis particularly under alkaline conditions, ${ }^{48}$ due to various reasons, $\mathrm{Fe} 3+$ changes to 
the insoluble forms of hydroxides and oxyhydroxides in alkaline soil, thus making iron unavailable to plants. Biofertilizers could play a vital role in the availability of iron, there are various bacteria produce siderophore like Azotobacter vinelandii, Bacillus megaterium, Bacillus subtilis, Pantoea allii, and Rhizobium radiobacter, while, Bacillus megaterium considered promising bacteria could use for correction of lime chlorosis in citrus cultivation under alkaline conditions, also, Bacillus subtilis and Azotobacter vinelandii produce siderophore with medium quantity. ${ }^{49}$

\section{Phytohormone production}

The biofertilizers produce various phytohormones stimulate citrus growth through the uptake of nutrients, enhancing photosynthesis process, regulating plant cell division and size, enhancing prolin production, Many studies confirmed the role of inoculation with these bio-fertilizers in releasing various phytohormones including cytokinins, gibberellins, indole acetic acid, auxins, and ethylene. Therefore, biofertilizers contribute a vital role to improve citrus plant growth and increasing yield, and enhancing citrus fruit quality. ${ }^{50-52}$

Indirect mechanism: Biocontrol agents considered efficient strategy in citrus orchards and safe for human health and protect the environment, without side effects on fruit quality.

a) Limiting the inhibitory effects of soil pathogens on plant growth through stimulating plant defense by enriching systemic resistance. ${ }^{10}$

b) Controlling citrus canker: widespread of citrus canker disease is in different citrus orchards worldwide affects negatively the growth and productivity of various cultivars, currently, the control of canker disease with biocontrol agents is a better strategy because it is safe for both consumers and the environment and usually does not have side effects on the fruit quality. ${ }^{20,53}$

The use of microbial antagonists to control citrus canker disease is currently an alternative strategy to combat disease, Sudyoung et al. ${ }^{37}$ reported that using microbial antagonists like Pseudomonas protegens and Bacillus amyloliquefaciens is promise method to control citrus canker.

\section{Arbuscular mycorrhizae and citriculture}

Currently, under harsh climate conditions that affect negatively citrus growth and productivity, Arbuscular Mycorrhizae could stimulate citrus performance and subsequently considerably enhances the tolerance of abiotic stresses particularly drought. ${ }^{53,54}$ Previous scientific studies have been indicated the mitigating effects in citrus plants subjected to abiotic stresses and describing the mechanisms of AM in improving citrus tolerance under adverse environments, ${ }^{24}$ AM enhancing the tolerance of citrus plants and stimulation plant growth performance through increasing chlorophyll levels, improving absorption of water and nutrients, regulation osmotic capacity, accumulation of antioxidants and osmolytes in plant tissue, synthesis of plant hormones, and improving soil fertility. ${ }^{56-58}$

\section{Conclusion}

Biofertilizers considered a promising alternative to synthetic agrochemicals to improve citrus orchards, there are various potential biofertilizers are used in citrus cultivation, due to their benefits including decrease environmental risks, enriching rhizosphere with nutrients, stimulate nutrients absorption, as well as enhancing biosynthesis of hormones and increased plant resistance to pathogens, and improve soil vitality.

\section{Acknowledgments}

None.

\section{Funding}

None.

\section{Conflicts of interest}

The author declares no conflicts of interest in this paper.

\section{References}

1. United States Department of Agriculture (USDA) (2016/2017) statistics.

2. Abobatta WF. Potential impacts of global climate change on citrus cultivation. MOJ Eco Environ Sci. 2019;4(6):308-312.

3. Khosro M, Yousef S. Bacterial bio-fertilizers for sustainable crop production: A review. APRN Journal of Agricultural and Biological Science. 2012;7(5):237-308.

4. Benrebah F, Prevost D, Yezza A. Agro-industrial waste materials and wastewater sludge for rhizobial inoculant production: A review. Bioresour Technol. 2007;98:3535-3546.

5. Vessey JK. Plant growth-promoting rhizobacteria as biofertilizers. Plant Soil. 2003;255:571-586.

6. Othman R, Panhwar QA. Phosphate-solubilizing bacteria improves nutrient uptake in aerobic rice. MS Khan, editors. Phosphate Solubilizing Microorganisms; 2014.

7. El-Badawy HEM. Partial substitution of Valencia orange chemical fertilization by bio- organic fertilization conjoint with algae extract foliar spray. Middle East J Appl Sci. 2017;7(4):1016-1030.

8. Cattelan AJ, Hartel, PG, Fuhrmann JJ. Screening for plant growthpromoting rhizobacteria to promote early soybean growth. Soil Sci Soc Am J. 61999;3:1670-1680.

9. Kang SC, Ha GC, Lee TG, et al. Solubilization of insoluble inorganic phosphates by a soil inhabiting fungus sp. Ps 102. Curr Sci. 2002;79:439442.

10. Vandenberghe LPS, Garcia LMB, Rodrigues C, et al. Potential applications of plant probiotic microorganisms in agriculture and forestry. AIMS Microbiology. 2017;3(3):629-648.

11. Jugnake MO, Patil MB, Shinde SE. Effect of biofertilizer and chemical fertilizer on growth and yield of sweet orange (Citrus sinensis L. Osbeck). International Journal of Chemical Studies. 2017;5(6):1061-1064.

12. Araujo FF, Henning AA, Hungria M. Phytohormones and antibiotics produced by Bacillus subtilis and their effects on seed pathogenic fungi and on soybean root development. World J Microbiol Biotechnol. 2005;21:1639-1645.

13. Stamenkovic S, Beskoski V, Karabegovic I, et al. Microbial fertilizers: A comprehensive review of current findings and future perspectives. Spanish Journal of Agricultural Research. 2018;16(1) e09R01.

14. Bashan Y, de-Bashan LE, Prabhu SR, et al. Advances in plant growthpromoting bacterial inoculant technology: Formulations and practical perspectives (1998-2013). Plant Soil. 2014;378 (1-2):1-33.

15. Abdelaal S, El-Sheikh MH, Hassan HAS, et al. Microbial bio-fertilization approaches to improve yield and quality of Washington navel Orange and reducing the survival of nematode in the soil. $J$ Am Sci. 2010;6(12):264 271. 
16. Abhilash PC, Dubey RK, Tripathi V, et al. Plant growth-promoting microorganisms for environmental sustainability. Trends Biotechnol. 2016;34 (11):847-850.

17. El-Aidy AA, Alam-Eldein SM, Esa MW. Effect of organic and biofertilization on vegetative growth, yield, and fruit quality of 'Valencia' orange trees. J Product \& Dev. 2018;23(1):111-134.

18. Grabber N, Galloway JV. An earth system of the global nitrogen cycle. Nature Publishers. 2008:293-296.

19. El-Khawaga AS, Maklad MF. Effect of combination between bio and chemical fertilization on vegetative growth, yield and quality of Valencia orange fruits. Hortscience J Suez Canal Univ. 2013;1:269-279.

20. Youssef MMA, Eissa MFM. Biofertilizers and their role in management of plant parasitic nematodes. J Biotech Pharma. 2014;5(1):001-006.

21. Gomez CG, Valero NV, Brigard RC. Halotolerant/alkalophilic bacteria associated with the cyanobacterium Arthrospira platensis (Nordstedt) Gomont that promote early growth in Sorghum bicolor (L.). Moench Agron Colomb. 2012;30:111-115.

22. Ghosh A, Dey K, Bhowmick N, et al. Reproductive behaviour of Lemon (Citrus limon Burm.) Affected by different pruning intensities and integrated nutrient management under various growing season. Int J Curr Microbiol App Sci. 2017;6(4):606-614.

23. Al-Karaki GN. The effect of Arbuscular Mycorrhizal fungi on the establishment of sour orange (Citrus aurantium) under different levels of Phosphorus. Acta Hort (ISHS). 2013;984:103-108.

24. Abobatta WF. Arbuscular Mycorrhizal and citrus growth: overview. Acta Scientific Microbiology. 2019;2(6):14-17.

25. Mohamed HM, Al- kamar FA, Azza AM, et al. Effect of Magnetite and some biofertilizer application on growth and yield of Valencia orange trees under El - Bustan condition. Nature and Science. 2013;11(6):46-61.

26. Bakshi M, Wali VK, Sharma A, et al. Economic Evaluation of Kinnow Mandarin cultivation using inorganic and organic nutrient sources along with biofertilizers. Int J Curr Microbiol App Sci. 2018;7(08):130-138.

27. El-Shazly SM, Mustafa NS. Enhanced yield, fruit quality and nutritional status of Washington Navel orange trees by application of some biostimulants. ISHS Acta Horticulture 1056; XII International Citrus Congress, International Society of Citriculture; 2015.

28. Singh AA, Thakur S, Sharma PPS, et al. Bio-inoculants enhance growth, nutrient uptake, and buddability of citrus plants under protected nursery conditions. Communications in Soil Science and Plant Analysis. 2018;49(20):2571-2586.

29. El Khayat HM, Abdel Rehiem MA. Improving Mandarin productivity and quality by using Mineral and Bio-Fertilization. Alex J Agric Res. 2013;58(2):141-147.

30. Shamseldin A, El-Sheikh MH, Hassan HAS, et al. Microbial bioFertilization approaches to improve yield and quality of Washington navel orange and reducing the survival of nematode in the soil. J Am Sci. 2010;6:264-271.

31. Ismail OM, Dakhly OF, Ismail MN. Influence of some bacteria strains and algae as biofertilizers on growth of bitter orange seedlings. Aust J Basic \& Appl Sci. 2011;5(11):1285-1289.

32. Ali Nadia AA, Soliman BM, Hassan MA. Effect of Azotobacter and different sources of organic matter on growth and nutrition of Valencia seedling in new soil. J Agric Sci Mansoura Univ. 2007;32(10):8553-8573.

33. Zayan MA, Sayed RA, El-Shereif AR, et al. Irrigation and fertilization programs for "Washington Navel " orange trees in sandy soil under desert climatic conditions. 1- Effect of soil properties, vegetative growth and yield. J Agric Res Kafr El-Sheikh Univ. 2016;42(2):210-233.
34. Masoud AAB, Abd Elaal AMK. Influence of using compost tea enriched with Spirulina Plantensis algae on fruiting of balady lime trees. Assiut $J$ Agric Sci. 2012;43(1):57-70.

35. Ennab HA. Effect of Organic Manures, Biofertilizers and NPK on Vegetative growth, yield, fruit quality and soil fertility of eureka lemon trees (Citrus limon (L.) Burm). J Soil Sci Agric Eng Mansoura Univ. 2016;7(10):767-774.

36. Usha K, Saxena A, Singh B. Rhizospheredynamics influenced by Arbuscular mycorrhizal fungus (Glomus Deserticola) and related changes in leaf nutrient status and yield of Kinnow mandarin King (Citrus nobilis) x Willow leaf (Citrus Deliciosa). Australian Journal of Agricultural Research. 2003;55:1-6.

37. Sudyoung N, Tokuyama S, Krajangsang S, et al. Bacterial antagonists and their cell-free cultures efficiently suppress canker disease in citrus lime. Journal of Plant Diseases and Protection. 2020;127:173-181.

38. Sharma S, Kaur M. Plant hormones synthesized by microorganisms and their role in biofertilizer- A review article. Int J Adv Res. 2017;5(12):17531762 .

39. Daniel Y, Tariku A. Components, mechanisms of action, success under greenhouse and field condition, market availability, formulation and inoculants development on biofertilizer. Biomed J Sci \& Tech Res. 2019;12(4).

40. Mehmood U, Inam-ul-Haq M, Saeed M, et al. A brief review on plant growth promoting Rhizobacteria (PGPR): A key role in plant growth. Plant Protection. 2018;02(02):77-82.

41. Glick BR. Plant growth-promoting bacteria: mechanisms and applications. Hindawi Publishing Corporation, Scientifica. 2012. 15 p.

42. Bargaz A, Lyamlouli K, Chtouki M, et al. Soil microbial resources for improving fertilizers efficiency in an integrated plant nutrient management system. Front Microbiol. 2018;9:1606.

43. Etesami H, Emami S, Alikhani HA. Potassium solubilizing bacteria (KSB): Mechanisms, promotion of plant growth, and future prospects - a review. Journal of Soil Science and Plant Nutrition. 2017;17(4):897-911.

44. Elavarasi P, Yuvaraj M, Gayathri P. Application of bacteria as a prominent source of biofertilizers. Intech Open; 2020.

45. Richardson AE, Barea JM, McNeill AM, et al. Acquisition of phosphorus and nitrogen in the rhizosphere and plant growth promotion by microorganisms. Plant and Soil. 2009;321(1-2):305-339.

46. Santi C, Bogusz D, Franche C. Biological nitrogen fixation in non-legume plants. Annals of Botany. 2013;111:743-767.

47. James EK. Nitrogen fixation in endophytic and associative symbiosis. Field Crops Research. 2000;65:197-209.

48. Correia PJ, de-Varennes A, Gama F, et al. Changes in nutritional homeostasis of Poncirus trifoliata and Ceratonia siliqua as a response to different iron levels in nutrient solution. Journal of Plant Nutrition. 2018;41(16):2103-2115.

49. Ferreira CMH, Vilas-Boas AM, Sousa CA, et al. Comparison of five bacterial strains producing siderophores with ability to chelate iron under alkaline conditions. AMB Expr. 2019;9:78.

50. Zahgloul AE, El-Din MN, Ghaz AA. Combination effects of biofertilization and biostimulants foliar application on yield, quality and marketability of Washington navel orange fruits. J Agric Chem Biotechn Mansoura Univ. 2015;6(12):627-655.

51. Ali B, Sabri AN, Ljung K, et al. Auxin production by plant associated bacteria: impact on endogenous IAA content and growth of Triticumaestivum L. Letters. Appl Microbiol. 2009;48(5):542-547. 
52. Spaepen S, Vanderleyden J, Okon Y. Plant growth-promoting actions of rhizobacteria. Advances in botanical research. 2009;51:283-320.

53. Michavila G, Adler C, De Gregorio PR. Pseudomonas protegens CS1 from the lemon phyllosphere as a candidate for citrus canker biocontrol agent. Plant Biol. 2017;19:608-617.

54. Liu CY, Zou YN, Zhang DJ, et al. Mycorrhizae and tolerance of abiotic stress in citrus plants. In: Giri B, editors. Biofertilizers for Sustainable Agriculture and Environment, Soil Biology 55; 2019.

55. Sharma SD, Kumar P. Relationship of Arbuscular mycorrhizal fungi and Azotobacter with plant growth, fruit yield, soil and leaf nutrient status of mango orchards in North -Western Himalayan region of India. Journal of Applied Horticulture. 2008;10(2):172-178.
56. He JD, Dong T, Wu HH, et al. Mycorrhizas induce diverse responses of root TIP aquaporin gene expression to drought stress in trifoliate orange. Sci Hortic. 2019;243:64-69.

57. Chen W, Li J, Zhu H, et al. Arbuscular mycorrhizal fungus enhances lateral root formation in Poncirus trifoliata (L.) as revealed by RNA-Seq analysis. Front Plant Sci. 2017;8:1-13.

58. Wu QS, Zou YN. Mycorrhizal symbiosis alters root $\mathrm{H}+$ effluxes and root system architecture of trifoliate orange seedlings under salt stress. J Anim Plant Sci. 2013;23:143-148. 